\title{
DESONERAÇÃO DA FOLHA DE PAGAMENTO - ESTUDO DE CASO EM UMA EMPRESA PRESTADORA DE SERVIÇOS NA CONSTRUÇÃO CIVIL
}

\section{Gabriele Bueno Goulart de Andrade ${ }^{1}$}

Resumo: O Brasil é um dos países da América Latina que possui o maior índice de carga tributária, principalmente os relacionados a encargos sociais. Devido a essas cargas elevadas, o mercado nacional vem perdendo posição e desvantagem econômica. Em agosto de 2011 o Governo Federal criou uma série de medidas provisórias chamado de Plano Brasil Maior, que consiste em estimular a inovação e a produção nacional. A pesquisa utilizada neste artigo é a Dedutiva, com estudo de caso e pesquisas exploratórias através de estudos bibliográficos $O$ caráter da pesquisa é a qualiquantitativa. Foram elaboradas planilhas em um quadro comparativo evidenciando os encargos sociais com e sem a desoneração na folha em uma empresa prestadora de serviços na construção civil e o resultado apresentado não pode-se dizer que a desoneração da folha de pagamento seja um incentivo fiscal do Governo Federal mas sim uma despesa fiscal que pode levar as empresas a reduzir seu número de empregados e aumentar o numero de desempregados ou empregados não formalizados.

Palavras-chave: Desoneração; Folha-de-pagamento; Encargos sociais; Construção civil.

\footnotetext{
${ }^{1}$ Docente/Anhanguera, Brasil. E-mail: gabriele.maville@terra.com.br.
} 